\title{
Goat's Blood, Tablets and Sacred Ivy
}

\author{
Nabil Ali \\ Independent Scholar and Creative Practitioner \\ Colchester, England.
}

\begin{abstract}
Introduction
Some recipes in historical painters' and illuminators' technical manuscripts can appear strange and unusual to our modern perception. Countless recipes were transcribed and copied from earlier books with some now lost and translated from one dialect to another, posing the risk of displacing the fundamental significance behind intended processes when formerly written (Clarke 2011). Some of these recipes may become apparent once further insight into the initial objectives regarding the process described are revealed. This however, may be recognised when the practical knowledge of the recipe is associated with the original cultural awareness, then examined from a multidisciplinary perspective from a multitude of various angles. Though we can not assume that all impossible or unusual recipes written by earlier practitioners were entirely accurate or indeed ethically correct, but were important enough to be noted. Indeed, there have been attempts to see through the misty realms of the antiquity, with multidisciplinary concepts opening challenging aspects of deciphering historical findings through forming an abundance of opinions.

The Art Conservator Srebrenka Bogovic argues that over time modern historians have unfortunately separated both disciplines of Artists and Alchemists, believing both dealt with the transcendental qualities of matter in unlocking the secrets of creativity which seemed to be closely aligned to each other in practice (Zeskoski 2017). Though it can be challenging and sometimes difficult to pinpoint the exactness from a singular perspective, yet we can acknowledge and agree that some unusual recipes complied in technical manuscripts do admittedly exist and seen as unconventional, due to limited or restricted insight. We recognise the language of alchemy was sometimes formulated in riddles to safeguard the knowledge by keeping the information in the hands of the wise, due to the dangers of corruption and misuse (Zeskoski 2017). If these recipes are seen from their original cultural settings and ethnical background, we could conceivably begin to unlock some of the enigmas behind certain obscure recipes. This could constitute an objective opinion towards acquiring a greater understanding - not just from a practical perspective - but from a profound aesthetic awareness with abstract thinking behind the processes concerned. It's plausible to assume that many recipes came from a more preceding period of artisans who may have incorporated mysticism or integrated an alchemic language into various
\end{abstract}


processes, being part of an alternative belief system and distinct way of living. With this in mind, determining values and methods may be considered into observing the concepts adversely to facilitate meaningful knowledge towards seeing the hidden detail - or the less obvious -demonstrating a more apparent perception into viable likelihoods.

Can we say that these recipes were Christian, Arabic or Greek? Or were they perhaps inherited from earlier cultures copied centuries ago from manuscript to manuscript finally to end up written within the Latin pages of painters' and illuminators' handbooks from the fourteenth-century? This developing study is a journey into understanding what may have been meant when goat's blood and ivy were used in craftsman's recipes and explores elements that held meaning in a different age.

\section{Tablets}

Before exploring goat's blood, we can briefly look at some of the ideas surrounding ancient tablets. There is a fourteenth-century manuscript called the Montpellier MS H 277, also known as the LDA - Liber diversarum arcium - which describes in recipe $\$ 4.37 .1 \mathrm{C}$ an unusual process for changing copper tablets into a golden colour using ivy berry juice and the blood from a goat. At first glance the recipe appears distorted or even absurd, impossible to our comprehension with the perception of unconnected practices and ideas perhaps becoming disjointed through multiple translations over time. Yet there may be some practical craftsmen's knowledge which existed within past processes and may have remained hidden from the understanding of the discipline.

However, if copper plates are heated to high temperatures, it transforms the oxides using a reduction process creating permanent colour sequences resulting in colours from purples, blues, greens, yellows, and blacks (Hinshelwood 1922; Evans 1925). To define this process, the previous LDA recipe $\$ 4.36 .1$ states numerous colours can be made by heating copper over time. Additionally, when the heated metal is cooled in goat's blood - and then again in ivy juice - as suggested in recipe \$4.37.1.C - the technique is to strengthen the metal termed 'quick quenching' (Wilson 1936; Moran 2009; The Historical Metallurgy Society 2017). This is conducted by swiftly dipping the heated copper tablet in and out of the liquid to the count of nine until it has cooled and toughened. Examples of similar processing can be found in Arnaldus de Bruxella's fifteenth-century manuscript having been copied from earlier Arab and Greek alchemic sources (Wilson 1936).

Below outline recipes translated by Mark Clarke highlighting some of the processes involved. It starts with recipe $\$ 4.36 .1$, 'On the reddening of auricalchum or other copper 36 th chapter', then recipe $\$ 4.37 .1 \mathrm{C}$, which mentions ivy juice and goats blood. 
Manuscript recipe $\$ 4.36 .1$ I $\$ 4.37 .1 \mathrm{C}-\mathrm{c} .1400^{1}$

The Liber diversarum arcium, Montpellier, MS H 277, fonds ancien, Bibliothèque interuniversitaire, section médecine, France (Clarke, 2011).

\begin{tabular}{|c|c|}
\hline English Translation & Original Latin Text \\
\hline $\begin{array}{l}{[\$ 4.36 .1]^{2} \text { To redden auricalcum [a copper }} \\
\text { alloy] or other copper, do thus: first polish it } \\
\text { on one side such that it shines well, then cover } \\
\text { it with linseed oil, and put that same copper } \\
\text { over the coals, and after it shall have lain there } \\
\text { for a long time, it will have various colours, if } \\
\text { you leave it a little, you will see a golden } \\
\text { colour, if more you will see reddish, if more } \\
\text { you will see scarlet, when you will see this } \\
\text { take it from the fire, and when it will be } \\
\text { weakened: with an instrument of iron, formed } \\
\text { thus:- you will engrave or draw as much as } \\
\text { you want, and that which you will draw will } \\
\text { appear gold; then apply on top the colour } \\
\text { which is applied on top of gold or silver } \\
\text { escutcheons, which is called 'doratura' }{ }^{3} \\
\text { [vermeil], and dry it. }\end{array}$ & $\begin{array}{l}\text { [ } \$ 4.36 .1] \text { Ad vermiculandum auricalchum vel } \\
\text { alium cuprum sic facias / primo rade in una } \\
\text { parte ut bene luceat / deinde superduc oleum } \\
\text { lini et super carbones ipsum cuprum ponas / et } \\
\text { secundum quod diu iacuerit / diversos colores } \\
\text { habebit / si dimittas parum / videbis aureum } \\
\text { colorem / si plus videbis subrubeum / si magis } \\
\text { vibebis scarlateum / cum hunc vibebis de igne } \\
\text { trahes / et cum infractum fuerit / cum } \\
\text { instrument ferreo sic disposito rimabis } \\
\text { quantumcumque volueris / vel designabis / et } \\
\text { quod designaveris / aparebit aureum / deinde } \\
\text { colore quem superinducunt clipearii auro vel } \\
\text { argento qui apelatur doratura superducas et } \\
\text { siccari facias. }\end{array}$ \\
\hline $\begin{array}{l}{[\$ 4.37 .1 \mathrm{C}] \text { If you want tablets of copper or }} \\
\text { auricalcum to exhibit the colour of gold, so } \\
\text { that to the sight of all it appears to be gold, do } \\
\text { thus: first take ivy, express its juice, then dip } \\
\text { the heated tablets in that same juice nine } \\
\text { times, when then this will have dried, have } \\
\text { blood of a goat, and in the same way heat in } \\
\text { the fire and dip nine times, and you will see } \\
\text { that, how much [ to the sight] there will be not } \\
\text { any difference from gold. }\end{array}$ & $\begin{array}{l}\text { [\$4.37.1C] Si vis cupri tabulas vel auricalchi } \\
\text { ad aureum repercutere colorem / ita ut visu } \\
\text { omnibus apareat aurum sic fac / accipe primo } \\
\text { ederam / sucum eius exprime / deinde tabulas } \\
\text { calefactas in ipso suca novies intinge / cum } \\
\text { autem hoc siccaveris / habeas sanguinem } \\
\text { yrcinum / consimiliter calefactas in igne } \\
\text { novem vicibus intingas / et videbis quod } \\
\text { quantum ad visum ab auro nulla erit } \\
\text { differencia }\end{array}$ \\
\hline
\end{tabular}

According to Le Begue's recipe $\$ 66$ from the fifteenth-century manuscript: Experimenta de Coloribus, it suggests ways to give a golden colour to any metal using

1. Clarke, Mediaeval Painters Materials and Techniques, 156. Recipe found in the LDA Book 4: Painting in other media, and auxiliary materials; Metallurgy

2. Ibid., 156. To redden copper, [Chp.36] - this recipe gives an insight into colour reduction processes and permanent colour sequences.

3. Ibid., 225. Doratura [vermeil] is a transparent coloured glaze applied over paint or onto metal. 
powdered red sulphur and orpiment which is heated in a crucible over fire. This was of course one process of many which gives ways to make a golden colour (Merrifield 1967). ${ }^{4}$

The LDA recipe is a practical instructive guideline to transform copper tablets into a golden colour. So why use goats blood at all? It can be said from a practical perspective that preparing solutions to harden certain tools such as files, are to be quenched in linseed oil or he-goat's blood, whilst cutting tools are cooled in the juices of radishes, earthworms and he-goat's blood and drill bits quenched in man's urine to toughen them (Moran 2009).

I'm suggesting the LDA's recipe ingredients may have originated from earlier belief systems due to utilising goat's blood in relation with ivy juice. Both factors can be associated with Dionysiac worship once widespread in parts of Ancient Greece as a foreign cult with the he-goat most loyal to Dionysus ${ }^{5}$ and a favoured sacrificial animal at the festival of Agrionia (Otto 1965). ${ }^{6}$ The LDA recipe does not specify that the tablets were ever intended for religious purposes or whether they were borrowed from earlier cultures, yet they do have parallel perspectives to past religious tablets having been made using real gold. Historically, tablets have been constructed from other materials in the past such as bone seen from the fifth-century BC Olbia tablets engraved with Bacchic inscriptions to Dionysus (Graf and Johnston 2013). Further materials used were bronze, wax, wood, stone, brass, iron, tin, lead, limestone, marble and indeed clay. ${ }^{7}$ Written examples can be found documented in the late Greco-Roman Greek Magical Papyri, ${ }^{8}$ detailing spells written on golden coloured tablets stylised as 'Hermes victory charms', sacredly applied to boats and horses that ferociously charge into the depths of the battlefield (Betz 1986). Pliny supports the theory that metal tablets originated from an ancient customary practices in making notices made out of brass to publicly engrave enactments on monuments to serve the state (Bostock and Riley 1855; Pliny and Rackham 1938). Plato and Aristotle also describe tablets made from Cypress wood, coated with chalk for temporary record keeping that can be wiped clean then reused again and descriptions written on golden coloured tablets utilised for special public laws with enforced policies (Rackham 1952; Bury 1967). These indeed were anointed with blood sacrificed from sacred animals strictly allocated for this purpose, whilst signifying oath invoking rites said to possess mighty curses upon those who directly violate the law of the State (Lamb 1925). Those who participated into special oath takings

4. Gettens and Stout, Painting Materials, 135, 152; Nicholson and Shaw, Ancient Egyptian Materials, 114-116. Orpiment $\left(\mathrm{As}_{2} \mathrm{~S}_{3}\right)$ a yellow pigment and Realgar $\left(\mathrm{As}_{2} \mathrm{~S}_{2}\right)$ an orange red sulphide of arsenic pigment two minerals that are often found together which are highly poisonous. Orpiment was used as a yellow colour on papyrus and as a layer with yellow ochre on tomb walls in ancient Egypt as early as c.2400 BC. (Also see: Eastaugh, Walsh, Chaplin and Siddall, Pigment Compendium, 285-6, 318-19).

5. Dionysus - god of wine and intoxication including ritual ecstasy and the fictitious world of the theatre.

6. Burkert, Greek Religion, 163. Festival of Agrionia - a festival of dissolution and inversion, with the woman's uprising madness and cannibalistic fantasies with goat sacrifices; Otto, Dionysus: Myth and Cult, 103-105, 118. Also it was the 'festival of the dead' pre-existing before the widespread worship of Dionysus, with myths of the Dionysiac woman hunted down in cult practice ending in tragedy.

7. Palomar, Hidalgo and Vilarigues, Pigments, Vinegar and Blood, 555-565. Assyrian clay tablets from the eighth-century $\mathrm{BC}$ explains glass making techniques written in cuneiform glyphs.

8. The 'Greek Magical Papyri' is kept in the collection of the Centro di Papirologia A. Vogliano. (Milan, Universitá Statale, Vogl. inv. 1245). 
- whether the devotees into cults, or citizenship and warriors going into battle - would dip theirs hands or weapons into the fresh blood for reassurance and abiding with the laws given by the State (Ekroth, 2014).

Elements from recipe $\$ 4.37 .1 \mathrm{C}$ have similar symbolic attributions relating to ancient Greek's blood rites for slaughtering goats and are symbolically connected to Dionysus the god of wine and intoxicated ecstasy, know to the Roman's as Bacchus, or Bakchos ${ }^{9}$ (Frazer 1994; Hall and Clark 1974). 'Aegobolus' was another epithet used to characterise the god, meaning 'Goat Killer', derived from an ancient myth when Dionysus substituted a goat for ritual sacrifice instead of using a youth (Peck 1897). Accounts can be seen when the blood was drained from the sacrificed animal into a sphageion vessel and stored in a wineskin disguised as a child in deceiving the gods (Ekroth 2005). However, the goat was a favoured victim in honouring certain gods and are associated with the goddess Artemis ${ }^{10}$ in sacrificing the animals before her, with further offerings to Hermes ${ }^{11}-$ the messenger of the Gods who led the souls of the dead into Hades (Burkert 1985; Jordan 2002)

In recipe $\S 4.37 .1 \mathrm{C}$ it does not present further insight into any deliberate processes for preparing goat's blood through religious ceremonies or sacred rituals and we need to ask if these concepts were ever incorporated or established at the beginning of the preparation stages for making such tablets. It is possible that the initial recipe information may have lost its original meaning when translated or copied from earlier manuscripts before compiled into the LDA, or were they independently transmitted directly from the actual workshop?

The earliest known copper tablets discovered are the Schøyen Collection MS 108, dating from the eighth-century BC and presents one of Europe's oldest writing tablets (Schøyen 2013). These artefacts illustrate an alphabet combining the Greek and Northern Semitic letters which are repeated over and over again, suggesting a student's learning book or a lost magical spell. Graf and Johnston have researched various ivy shaped golden tablets found in graves from the regions of Magna Graecia, Sicily, Thessaly and Crete, dating from the fifth-century BC to the second-century AD. Several of the tablets belonged to deceased men and women initiated into the secret worship of Dionysiac mysteries, with the belief that these tablets would protect them when encountering the treacherous journey through the depths of the underworld (Graf and Johnston 2013). Statuettes of maenads were also discovered in some of their sarcophagus with ivy shaped tablets found placed upon their chests and across their mouths, inscribed with incantations and sacred text describing a journey into the Hades with cult deities and reassurances:

\footnotetext{
9. Roberts, The Oxford Dictionary of the Classical World, 230-232; Hall and Clark, Dictionary of Subjects and Symbols in Art, 37. Bakchos - commonest cult name for Dionysus with his followers called Bakchai adopted by the Romans as Bacchus.

10. Ibid., 101. Artemis - Mistress of Animals and the goddess of blood sacrifice, she is the daughter of Zeus and Leto.

11. Jordan, Encyclopedia of Gods, 99. Greek god Hermes regarded as a grave guardian and was equivalent to the Roman god Mercury / Mercurius.
} 
“...Now you have died and now you have come into being, O thrice happy one, on this same day. Tell Persephone ${ }^{12}$ that the Bacchic ${ }^{13}$ One himself released you. Bull - you jumped into milk. Quickly - you jumped into milk. Ram - you fell into milk. ${ }^{14}$ You have wine as your fortunate honor. And below the earth there are ready for you the same offices as for the other blessed ones..." (Graf and Johnston 2013)

Inscriptions on other leaf shape tablets reference Bacchus and the mountain mother, where it is said Dionysian followers on mountainsides held their secretive rites and earthly celebrations (Roberts 2016; Winnington-Ingram 2003):

“...I am son / daughter of the Earth and starry sky'; - 'who posses the sacred rituals of Bacchus'; [and] - 'rites of the mountain mother'; [for the journey after death to Hades ${ }^{15}$ in order to] 'drink from the lake of memory..."16 (Graf and Johnston 2013).

The text could be the deceased 'initiation rites' into the cult whilst still alive, before becoming part of an Orphic secret society or Dionysiac cult through visual contemplation. As Edmonds suggests these tablets could have been worn as magical amulets by the living rather than just been used as a burial ritual once the cult members became dead (Edmonds 2004). It is possible that the descriptive text was inherited from earlier belief system such as the mortuary practices with ritual parallels to those found in the Egyptian Book of the Dead. It is known that the Ancient Greeks adopted elements of the Egyptian cult of Osiris ${ }^{17}$ and readapted the concepts to their own culture (Renouf 1893; Graf and Johnston 2013; Burkert 1985; Cotterell 2003). The Greek historian Herodotus (c.480-c.425 BC) argues in his Histories book that the ceremonies in Dionysiac worship were introduced into Greece from customs seen in Egypt, with few ritual variations found from each practice (Orphic and Bacchic). He further asserts the Egyptian god of the dead, Osiris, ${ }^{18}$ was known to the

12. Roberts, The Oxford Dictionary of the Classical World, 550.

Jordan, Encyclopedia of Gods, 200. Persephone - goddess of death and the daughter of Zeus and the corn goddess Demeter.

13. Ibid., 34. Bacchic [Bacchus] is the Roman equivalent of Dionysus.

14. Patrich, Was Dionysos, the Wine God,95-113. It was pointed out by Patrich that the Arabs cooked a kid in its mother's milk, yet it can be debatable if this was what is suggested in the engraved tablet;

Graf \& Johnston, Ritual Texts for the Afterlife, 129. Yet the text does suggest honoured with wine which may be drunk at a feast in the afterlife. The meaning of "fall into milk" or "leap into milk" perhaps expresses happiness, midst of abundance or to make new beginnings.

15. Roberts, The Oxford Dictionary of the Classical World, 321. Hades - 'Lord of the dead', king of the Underworld, the 'House of Hades', where he rules supreme. Pluton became Hades in the fifth-century BC.

16. A further in-depth study into the Greek golden tablets can also be found in Edmonds, Myths of the Underworld Journey and Edmonds, The'Orphic'gold tablets and Greek Religion.

17. Cotterall, A Dictionary of World Mythology, 8-9. Graf \& Johnston, Ritual Texts for the Afterlife, 76, 91. Osiris possibly of foreign origin, he was the Ancient Egyptian chief deity of death, wine, agriculture and the initiator of religious rituals. He was known to the ancient Greeks in association of other cults and parallel to Dionysus myths.

18. Cooper, Traditional Symbols, 88. The ivy was the plant of Osiris - immortality, having similar attributes to that of Dionysus. 
Greeks as 'Dionysus' and in the language of the Arabs were identified as the wine god Orotal(t) (Waterfield and Dewald 2008). However, this has been disputed by Patrich that the Arabian Orotal(t) had little to do with the drinking wine aspect of Dionysus, but perhaps another aspect of this god (Patrich 2005). ${ }^{19}$ Therefore, we cannot rule out a possibility of a Arabic connection to the LDA recipe in relation to their understanding of Dionysus as an ancient Arabian $\operatorname{god}^{20}-$ if the recipe appears to be far older that the medieval period. There have been numerous theories on where Dionysus originated from and whether he was a concept name for making wine or for the wine itself. Yet the possibility can be dated as far back to the Early Dynastic periods of Egypt (c.2789-2658 BC) with the arrival of the 'Lord of the Wine' part of the ancient intoxicating Festival of Uaka ${ }^{21}$ mentioned in the Egyptian Pyramid Texts (Renouf 1893; Allen and Der Manuelian 2015; Massey 2007).

A further second-century BC half moon shaped golden tablet ${ }^{22}$ was found folded up and placed on the chest of the deceased from the region of Mylopotamos, with few lines engraved ending "“Who are you? Where are you from?" - 'I am daughter of Earth and Starry Sky' (Graf and Johnston 2013). These inscriptions may have echoed earlier cultural beliefs, with parts of the original understanding remaining at the time of the Greeks with parts of it lost. The distinctive curvature shape of crescent moon is represented on the head of ArtemisDiana, ${ }^{23}$ who was widely worshipped in Greek and Greco-Roman societies, as was Selene - the Greek moon goddess. ${ }^{24}$ Within chapters of the third/fifth-century Greek Magical Papyri from Greco-Roman Egypt, it explains how to make a statue in the image of Selene using potter's clay, sulfur mixed with the blood of a goat and when dried, anointed with oils. Further chapters define ways to create the figure of Hermes using orange beeswax, the

19. Resto, The Arabs in Antiquity, 613. Apparently there were dividing lines between wine drinkers and teetotallers Arabs regarding the Arabo-Nabataean Kingdom, therefore the duality of meaning is fragmented.

20. Patrich, Was Dionysos, the Wine God, 95-113; Jordan, Encyclopaedia of gods, 190. Orotal(t) - thought to compare with the northern Arabian deity Ruda (Ruldaiu) - the evening star, also known as Dushara -Dionysus among the Nabataeans - which according to Patrich was a 'wine-shunning' deity.

21. Renouf, The Egyptian Book of the Dead, Chapter 128, 256. Festival of Uaka - a time of intoxication and feasting associated with Osiris as Orion 'the Lord of Wine'(Vinosus) and the goddess Hathor/Isis.

Massey, Ancient Egypt, 572, 575. It is said that the original festival of Uaka is the same festival as Christmas - Winter Solstice, death/sleep and the return of the sun in becoming the New Year as rebirth.

22. Crescent moon - its shape represents either the waxing or waning before or after the new moon (dark moon), but can also represent a solar eclipse showing a daytime crescent.

23. Roberts, The Oxford Dictionary of the Classical World. Artemis-Diana - Mistress of Animals and the goddess of blood sacrifice, she is the daughter of Zeus and Leto.

Fischer-Hansen \& Poulsen, From Artemis to Diana, 29, 401, 408. A second-century marble statue of Artemis-Diana can be seen in the Chiaramonti Museum, Vatican City. Artemis is a very old cult that was mentioned in inscriptions on the early Greek 'Linear B' clay tablets dating back to the fourteenth-century BC and being associated with the goddess of the hunt.

Betz, The Greek magical papyri, 332. Artemis-Diana is identical with Selene, Hekate and Persephone.

24. Ibid., xlvii, 333, 141. Selene-Artemis was associated with the 'constellation of the Bear' and the light of the moon.

Jordan, Encyclopaedia of gods, 96, 231. Selene - Greek moon goddess probably Thracian or Phrygian origin, guardian deity of magicians and syncretized with Hekate - the patroness of witches - who plays a part in the return of Persephone from Hades. 
juice of plants and the ground ivy plant (Betz 1986).

If we return back to the LDA, recipe $\$ 4.37 \mathrm{~A} .2$ explains ways to make a statue of a satyr $^{25}$ using this recipe written in the same chapter as the golden tablets and 'inextinguishable fire', which was called 'Greek fire' - made with the strongest red wine, sulphur, tartar, rock salt ${ }^{26}$ (Clarke 2011). The lustful, drunken woodland spirit or a goatman, the satyr was associated with Dionysian revelry seen on numerous vases and Greek artwork as mischievous beings chasing maenads with flute blowing music and wild erotic dancing (Delahunty and Dignen 2012). Therefore, are these recipes Greek by nature?

One of the earliest tablets from the late bronze age is the Mycenaean Linear 'B', dating back to the fourteenth-century $\mathrm{BC}$ and displays the name of Artemis - or that of her festival - with attesting quantities of goats sacrificed in honouring the goddess (Fischer-Hansen and Poulsen 2009). Even though she wore the crescent moon it was not only associated with the feminine, but also connected with the ancient Egyptian god Thoth ${ }^{27}$ by having the crescent of the moon placed above his head on a diadem. In mythology and through philosophical understanding, he had connections with the goddess Isis ${ }^{28}$ - the daughter of Geb, ${ }^{29}$ who represented the 'Earth', and $\mathrm{Nut}^{30}$ being the 'sky' or the 'heavens night sky' - maintaining the same visual concept to the crescent tablet found in Greece. These may be part of a broader belief system of metaphors relating to the ancient agricultural society and the calendar cycles of the moon from an ancient Pagan cult. The customs surrounding Isis with the relationship with the dead and other attributes, had similar purposes to those that belonged to her in the Greco-Roman period with parallel readapted divinities (Budge 1969a; 1969b).

Yet it must be pointed out that gold in ancient Greece was a rare commodity (Roberts 2016), as funerary tablets were reserved for the aristocratic elite initiated into secluded communities and were able to afford the precious metals to be made into sacred amulets for funeral rites or jewellery (Edmonds 2004). The LDA recipe describes using inexpensive copper for imitating golden tablets which through the forging practices could be formed into

25. Ibid., 230; Cooper, Traditional Symbols, 144. Satyr - depicted in classical Greek Art. It also includes the Greco-Roman hoof-footed God Pan and the demi-god Silenus who raised Bacchus -whilst wearing the ivy crowns of Dionysus, Satyrs were the counterparts of Maenads.

26. Clarke, Mediaeval Painters Materials and Techniques, 156-158. Recipes §4.37.1C, §4.37A.1, §4.37A.2, §4.37B.3, $\$ 4.38 .6 \mathrm{~B}$, all part of the same chapter that reference goats and Greek fire made with wine.

27. Betz, The Greek magical papyri, 79, 339. Thoth - the moon god of the time and magic(k), writing and language, the arts and sacred sciences. The Ancient Greeks knew Thoth as Hermes Trismegistos, the elder chief of all magicians and deeper wisdom.

28. Budge, The Gods of the Egyptians vol.1, 150-151, vol.2, 141-147. In Egyptian Mythology, Isis, the female counterpart of Osiris, obtained divine ritual knowledge from Thoth (Crescent Moon) to triumph over death so Osiris can reign in the Underworld. It is said that the deceased in the Egyptian Book of the Dead, must enter the Judgment Hall of Osiris in the Weighing of the Heart ceremony, with their heart balanced against the feather of truth on the scales of Maat (law and divine order), with Thoth being the scribe/keeper of records watched by the jackal headed Anubis - God of the Dead, with awaiting consequences for the guilty.

29. Ibid., 98. Geb or Seb, associated with the earth and Lord of the Underworld and akin to the two Akeru lion headed gods of 'yesterday and today'; Ra, fire or sun; Shu, air or atmosphere; and Osiris, Water.

30. Ibid., 100-112. Nut female counterpart of Geb or Seb personification of the Night-sky and associated with various trees and the watery abyss. 
additional objects resembling real gold. As previously mentioned, recipes to prepare tablets could have been used for public policy announcements or for writing learning alphabets as the availability of copper was cheaper to utilize than using limited and expensive materials such as gold.

\section{Goat's Blood and Sacred Ivy}

Recipes which document ivy berries can be few, yet some have found their way into medieval painter's manuals copied and translated from earlier texts now lost over time or still yet to be discovered (Clarke 2011). In some recipes they show the importance of practical knowledge for making gold colour, using berries and blood through alchemic processes derived from ancient customs preserved in written form. The Middle Ages inherited the valuation of blood borrowed and simulated from earlier cultures, with the thinking adopted by different trades and establishments. At this point, they may have placed their own spiritual meaning and understanding of the significance of life and death in blood form, by altering or modifying the original concept or belief. This in mind, the medieval church and courts of the nobility had influenced the mindset of society by integrating attitudes towards blood (Bildhauer 2003). Parallel similarities can be seen between the Christ figure and that of Dionysus or indeed the god Osiris and their different cultural variations, with comparable symbolism regarding wine, ivy, blood, overcoming death and rebirth, drinking cups, peacock birds, seasonal festivals and so forth (Henrichs 1984). Therefore, having a blood-related recipe in medieval technical recipes may have had ritual connotations as well as just being a practical recipe to make or change an artisan's object to a given colour. We could ask why goats were only fed ivy leaves before sacrificing them as described in Bodleian MS $\S 10$ r below and whether this was necessary or habit in tradition? A possible cause may suggest that if the goat and ivy are attributed to Dionysus, it could signify honouring the god through obtained ancient inheritances and belief customs having been modified over time. The recipe implies starving the goat for several days before exclusively feeding the animal on ivy leaves, which may help to drug the goat by making the animal docile to lessen its struggle before finally been killed. This may be feasible due to the side effects on the nervous system from consuming considerable doses of ivy leaves when eaten, causing constriction of the blood vessels by slowing down the heart limiting oxygen to the brain (Bunney, et al. 1992; Beck 2011). However, there are discrepancies in opinion regarding the toxicity impacts from the ivy plant on goats after they have eaten large quantities and whether the leaves harm the animal or not once consumed. Pliny points out that goats did tend to self medicate on ivy leaves (Pliny and Rackham 1938) and in medieval Phillips-Corning recipe $\$ 289$, it acknowledges the goat after stimulating the animal with nettles by feeding it on ivy leaves, yet in the following recipe the goat is not so fortunate (Smith and Hawthorne 1974). ${ }^{31}$

31. Phillips-Corning Manuscript, Corning Museum of Glass, (Corning NY), Rakow Research Library Ms. 5. 
Below is a Middle-English recipe translated by Clarke which resembles similar processes to Theophilus recipes for toughening the tools to cut and engrave glass using goat's blood.

Manuscript recipe $\$ 10 r-c .1500$.

Bodleian MS e Musaeo 52, f. $65^{\mathrm{r}}$, §10r - (Clarke 2016).

\begin{tabular}{|c|c|}
\hline English Translation & Original Middle English Text \\
\hline $\begin{array}{l}\text { [\$10r] For to make crystal soft, take a goat } \\
\text { buck and keep him without food for } 3 \text { days, } \\
\text { and the next day feed him on ivy leaves, and } \\
\text { all the three days keep his urine in a vessel, } \\
\text { and then let him bleed out of the vein in the } \\
\text { side of his neck, and then mix the urine with } \\
\text { the blood - of each [of the urine and blood] } \\
\text { the same amount - and see that they are both } \\
\text { warm when you mix them together, and } \\
\text { almost just as warm lay your crustal or what } \\
\text { other stone you want therein, and it shall grow } \\
\text { soft such that you can engrave therein what } \\
\text { you want. }\end{array}$ & $\begin{array}{l}\text { [\$10r] For to make cristall nesshe, take a gote } \\
\text { buke and kepe hym withou3t mete } 3 \text { dayes, } \\
\text { and pe next day kepe hym with yve levys, and } \\
\text { alle pe } 3 \text { dayes kepe his uryne in a vessell and } \\
\text { pen lett hym blode ouer pe veyne in pe syde } \\
\text { of his neke, and pen medell pe uryne with pe } \\
\text { blode of eyther elych moche and loke pat be } \\
\text { bothe warme when pu medeleste hem togeder, } \\
\text { and nygh ry3te so warme ley pi cristall or } \\
\text { what oper ston pu wolt perin and it schall } \\
\text { waxe nesshe pat pu my3te graue perin wat pu } \\
\text { wylt. }\end{array}$ \\
\hline
\end{tabular}

Theophilus Presbyter the twelve-century Benedictine monk, ${ }^{32}$ describes in his craft treaties: De diversis artibus (London, British Library, MS Harley 3915), a recipe to make 'Spanish Gold', using the blood from red-headed man, vinegar, copper sheets and the powder made from a mythical creature called a 'basilisk' ${ }^{33}$ The recipe appears to have been borrowed by the Arabs, perhaps after the Norman-led Christians conquered Sicily in the eleventh-century (Metcalfe 2003). Theophilus comments: 'The heathens [Arabs], whose skill in this art is commendable, create basilisks for themselves in this way' (Hawthorne and Smith 1979). He continues to describe in detail the recipe process to acquire goats blood by piercing its heart - perhaps in sacrifice - to drain and obtain the warm blood. Rock crystal is suggestively placed into the goat's blood to soften the crystal before carving onto it - or

32. Hawthorne \& Smith, On Divers Arts, xvii. Theophilus manuscripts - twelve-century MSS: (Vienna, National Bibliothek, 2527; Wolfenbüttel, Herzogliche Bibliothek, 4373) or (Cod. Guelph Gudianus lat. $2^{\circ} 69$. G); thirteenth-century MSS: (BL MS Harley 3915, De diversarum artibus). There are also copied MSS which date from fourteenth or fifteenthcentury (see Clarke, Mediaeval Painters Materials and Techniques).

33. Cooper, Traditional Symbols, 63. Zeskoski, Historical Pigments, 21-41. Basilisk - a bird and reptile combination, head and claws of a bird and body of a serpent. Each part of the animal could be part of an old alchemic language and theory relating to particular elements used in alchemy. 
with the theory of tempering engraving tools in blood to harden them before carving onto quartz stone or similar gems. ${ }^{34} \mathrm{He}$ also describes the technique on how to bind a young goat with ivy vines, which is starved for several days. On the fourth day the animal is solely fed on ferns, with the goat's urine collected to practically temper iron instruments within it to continue to cut glass with them. (Hawthorne and Smith 1979; Eastaugh, et al. 2004) ${ }^{35}$ Here it seems the quick quenching technique is applied for toughening the tools, but within this recipe the animal is not sacrificed but released. Pliny documents similar practices which were known to the Greeks, using the fresh blood of a he-goat to assist in breaking a semiprecious stone called 'Adamas' ${ }^{36} \mathrm{He}$ also mentions the 'serpents called Basilisks', which destroys animals, wildlife and contaminates the soil by their breath (Bostock and Riley 1855; Pliny and Rackham 1938). These elaborate creatures were mentioned earlier by the Roman Poet Macus Annaeus Lucanus, or Lucan (c.39-65 CE) in his lengthly poem Pharsalia - Civil War. The entirety of the poem descibes the battle of Pharsalus c.48 BC, fought on the Emithian fields of Thessoly in Northern Greece (Howatson 2011).

He writes:

"...the Basilisk which pours forth hisses terrifying all the beasts, which harms before its poison and orders the entire crowd far out of its way and on the empty sand is king What good is it that the Basilisk is pierced by miserable Marrus' spear? The poison swiftly runs along the weapon and attacks the hand; he straight away unsheathes his sword and by striking the hand in one blow he severed it entirely from his shoulder and gazes at the pitiable pattern of his own death as he stands safe as his hand dies..." (Braund 1992).

We need to consider if the deadly basilisk beast mentioned in medieval recipes signified an original concept name for some sort of biochemical weapon released on Greek or Roman battlefields in the form of poison gas? Once a natural phenomenon which occurs in nature, then amplified by the experimental alchemist in replicating the drastic effects it can unleash - or conversely, used as a localised deterrent in North Africa against invading warriors or treasure-hunting thieves?

If we look at a fifteenth-century Hebrew manuscript: British Library Or. 3659 originally copied from an eleveth-century manuscript written by a Sicilian Arab alchemist

34. Hawthorne \& Smith, On Divers Arts, 189; Gettens \& Stout, Painting Materials, 156. Theophilus describes Rock Crystal is water hardened into ice, which is hardened through many years into stone. Rock Crystal - silica material, quartz, can be ground down into small particles to a form powder.

35. Eastaugh, et al., The Pigment Compendium, 193. Solely feeding an animal one kind of food to produce a colour was also practiced in India, when a cow was only fed on mango leaves (Mangifera indica Linn). The animal's urine became bright yellow and after the distilling processes made into an artist's organic paint called 'Indian Yellow' between the fifteenth and nineteenth-centuries. Eventually the manufacture and practice became prohibited by law in India due to the suffering and inhumane nature caused to the animals involved.

36. Clarke, Tricks of the Medieval Trades, 11. Adamas - a hard, colourless, precious or semi-precious stone, such as diamond or similar. 
called Abufalah of Syracuse - it highlights what a basilisk in relatity was and how to make ashes from it (Patai 1995). ${ }^{37}$ This was described by Theophilus as a 'basilisk powder' in his twelth-century 'Spanish Gold'recipe, and according to Abufalah, thirty to forty eggs are broken then placed inside a sealed pot which is buried in warm dung for forty days. He then mentions attaching a crooked hollow reed through a hole made in the pot's lid so the deadly hydrogen sulphide gases which were built up could escape. ${ }^{38}$ The pot is kept in the dung for a further forty days allowing the eggs to become mouldy, morphing into a basilisk creature - or what appears to look like an serpentine creature - that will cause death, distruction and decay. It is then thrown into a heated pan to burn the mouldy beast until becoming the ashes of a basilisk. Abufalah the alchemist once from Syracuse ends by saying "this operation [recipe] has in truth no value", or the uses for the recipe were not needed by this alchemist for any particular purpose or intentions (Patai 1995; Law and Rennie 2020).

Centuries earlier, the fourth-century writer Firmicus Maternus of Syracuse, conducted an attack on Dionysiac cults and effigies to eradicate their worship from all the lands (Hornblower, Spawforth and Eidinow 2012). In his book De errore profanarum religionum, he venomously scapegoats Dionysus as a dangerous demonic entity, equivalent to the Devil with all that is corrupt using the analogy of him being a basilisk and the scorpion, and writes:

“...He [Dionysus], is the 'basilisk' and the scorpion who is stepped on by the sure footstep of the believers; this evil reptile, whose head mortals seek to stroke, that sinuous dragon, who is led along by a fish hook, who is captured and imprisoned..."

(Mac Góráin 2019).

This of course laid the foundations for persecutions and religious prejudice for the coming centuries in breaking down the old religious systems and practices with profound suspicion planted between different people (Johnson 2009; Metcalfe 2003) ${ }^{39}$ This increased the gap between languages and communications from a multitude of different societies, reducing the understanding by a surpressing governing system. However, fragments of the craftsmen knowledge had survived and continued, with some of the intrinsic knowledge still locked in translation waiting to be released and better understood.

37. Patai, The Jewish Alchemist, 98. Abufalah's alchemic book called 'Em haMelekh' (Mother of the King), was very influential among the Jewish alchemists and their circles and was continued to be utilised two centuries after its composition. The book begins: "Said Abufalah the Saraqusti: Thanks to God who ordered the things and taught the sons of men their knowledge".

38. Law and Rennie, A Dictionary of Chemistry; Cullimore, Microbiology of Well Biofouling, 35. Hydrogen Sulphide $\left(\mathrm{H}_{2} \mathrm{~S}\right)$ is released from rotten eggs with the organic gas fatal to humans if inhaled or touched - as described in Lucan's poem. It is exceedingly poisonous and more toxic than Hydrogen Cyanide (HCN). Pseudomonas fluorescens is one of many kinds of versatile bacteria that develops in rotten eggs and is also hazardous to health.

39. Johnson, Peacemaking and Religious Violence, 2; Metcalfe, Muslims and Christians in Norman Sicily, 8, 26, 28, 97 8. Emperor Constantine converted to Christianity in the fourth-century making it the official religion of the Empire, with other religious, Jewish and Pagan, then became the objects of persecution by the government. Later, Islam grew rapidly clashing with Christianity and vice-versa leading to conflicts and disagreements. 
A fifteenth-century manuscript copied by Le Begue has similar practices to those of Theophilus' recipe on how to soften or sculpt glass, by feeding a goat strong ivy leaves before binding the animal to sacrifice. Interestingly, Le Begue's recipe comments on freshly dug worms to be thrown in with the goat's blood and vinegar, perhaps to redden the colour. From the same manuscript, it explains ways to temper iron for cutting stones by using goat's fat which toughened the edges immediately (Merrifield 1967). ${ }^{40}$

Ivy leaves seem to be play a part in many of the goat recipes and can be seem as a food source for the animal. Ivy was noted in the first-century by the Greek philosopher Plutarch (c.46-120 CE) who describes how the leaves were ripped to pieces by maenads chewing them in frenzy, in consuming the god [Dionysus] by eating the plant to become him in spirit (Dodds 1940; Plutarchus 1927). ${ }^{41}$ This gives a glimpse into some of the activities related to the philosophy of Dionysiac worship, yet the deeper understanding may have been lost in observation, perception and lack of understanding. A similar practice has surfaced in more recent times, when individuals ate and consumed ivy leaves - whether for experimental ritual exploration or just for a recreation curiosity buzz - unfortunately, this inquisitiveness led to the person's death by suffocation in a public space (Gaillard 2003). The practice of Maenadism attracted many female followers in ancient Greece and were spellbound by Dionysiac beliefs. Originally their spiritual practice excluded most men until the maenads' passions were overwhelmed by ecstatic rage and uncontrollable delusions. Their possessed minds released aggressive sentiments upon wild animals and the unfortunate short-sited male, as dramatised in Euripides' tragic play 'The Bacchae' (c.408 BC). This led to the death of Pentheus who was attempting to forcibly suppress the Dionysiac cult, but unfortunately was torn apart by his mother whilst she was under a frenzied state of mind. (Winnington-Ingram 2003; Golder 2001). ${ }^{42}$ In the height of the maenads' madness, or possessed mindset in trance, according to some scholars it is suggested that maenads had little to do with the consumption of drugs or alcohol that reflected their erratic behaviour (Roberts 2016). The evidence relating to the mindset of maenadic practices can be very fragmentary of the activities which were actually performed by the followers of these secret orders. Yet the Greek poet and play writer Euripides (c.480406 BC), describes maenads' having ecstatic pleasures and satisfactions under the influence of Dionysus, by eating raw goats flesh and drinking blood at annual festivals and in sacrificial rites (Golder 2001). Yet these blood thirsting customs of sacrificing gods in animal form belong to a very primitive stage of human culture and may have merged into orderly society at the beginning of the modern developments of Greece (Frazer 1994). Animal sacrifices across Greece were openly practised in favouring the gods, using art in

40. Clarke, The Art of all Colours; Mediaeval Painters Materials and Techniques, 20; Merrifield, Medieval and Renaissance Treatises on the Arts of Painting, 186, 196. IV, Of Sculpturing Glass; XIII, Of Tempering Iron - Le Begue, De Coloribus et Artibus Romanorum, Paris, Bibliothèque nationale de France, Latin MS 6741, originally written by Eraclius $=$ Heraclius, tenth-century .

41. Roberts, Dictionary of the Classical World, 442. Maenads - women inspired to ritual frenzy by Dionysus; Maenadism: a women's secret cult and devotees to Dionysus.

42. Burkert, Greek Religion, 165. Pentheus - an ancient Greek king of Thebes who was outwitted by Dionysus. 
communal rituals in serving a purpose within a belief or desire in obtaining a collective mind through an altered state of consciousness (Burkert 1985; Harrison 1913). As they were part of daily life, goat's blood was incorporated into the traditions of Greek medicine by mixing it with red earth for medicinal purposes ritually performed and sacredly made by the high priests and healers to support the sick (Hendrie 1847). In the writings of the firstcentury physician and botanist, Dioscorides wrote remedies against poisoned wine prescribing baked blood of a he-goat consumed straight out of the pan with the animal's urine drunk daily. It was proclaimed to treat abdominal humors and earaches and whether this medicine worked or not is debatable, but Dioscorides medicinal plant work and remedies were used up to the early nineteenth-century (Beck 2011). Pliny also states in his 'Naturalis Historia' book that when goat's blood is used with its marrow, it has beneficial health properties especially when the animal was fed on the ever-green shrub lentisk (Pistacia lentiscus). ${ }^{43}$ He further explains that the statues of Jupiter were painted using minium (red lead) or with other red pigments such as vermilion or red ochre, which was added to goat's blood during annual festivals possible to prolong the colour of the stain or used as a pigment binder for exterior paint (Eastaugh, et al. 2004). ${ }^{44}$ This illustrates religious practices using animals blood on pieces of art to mentally evoke favourable gods through public rituals and celebrations in ancient Greece (Bostock and Riley 1855; Pliny and Rackham 1938; Gettens and Stout 1966). Whether there was any logical evidence to suggest these practices ever worked using magical rituals or theatrical performances is somewhat debatable. Yet the pragmatic factors described in some of these ancient texts may have had beneficial properties with the practical application of making colour or religious objects across different periods of human development.

Several medieval recipes translated by Clarke explain ways on how to soften and strengthen glass using "luke-warm goat's blood boiled with the juice of the mustard plant to become soft as paste" (Cambridge, Trinity College MS 0.9.39 - recipe §28) (Clarke 2018). Many of the recipe descriptions show surface application and can seem impossible or fragmented, yet with recipe $\$ 28$ it could have derived from books previously written centuries earlier by Heraclius (Clarke 2016). ${ }^{45}$ Examples can be found later in the fifteenthcentury Arnaldus de Bruxella Alchemic manuscript, explaining various plants added to the metallurgy processes, originally dating back to alchemists from the thirteenth -fourteenthcenturies. Further recipes from Arnaldus are attributed to a tenth-century Arab called Abu Bakr Muhammed ibn Zakariya al-Razi ${ }^{46}$ and Jabir ibn Hayyan, or simply known as Geber

43. Gettens \& Stout, Painting Materials, 34. Lentisk (Pistacia lentiscus) - a plant that bleeds aromatic glass-like semi transparent resin becoming soft when heated and used for (Mastic) varnishes.

44. Jordan, Encyclopedia of Gods, 123, 297-98. Jupiter - the Roman equivalent to the Greek god Zeus, the father of Dionysus.

45. Clarke, Mediaeval Painters Materials and Techniques, 20; Merrifield, Medieval and Renaissance Treatises on the Arts of Painting, 182. Heraclius - De coloribus et artibus Romanorum: Book I and II likely date from tenth-century or perhaps much earlier. Book III is much later from around twelfth or thirteenth-century.

46. De Aluminibus et Salibus. 
from the ninth-century ${ }^{47}$ (Wilson 1936; Clarke 2001). An example of this can be found in the late twelve-century Phillips-Corning Manuscript ${ }^{48}$ and explains methods and techniques used by the Saracens to cut glass. ${ }^{49}$ It begins by forcing milk from a she-goat by thumping its udders and using stinging nettles, then applying the carving tools into the heated milk using the quick quenching technique to harden iron. The recipe also appears to have folklore attached to it or particular unknowns, suggesting to collect the urine of a red-headed girl before sunrise and used as an alternative liquid than goats milk. It additionally explains other gems can be softened and cut using this technique. (Smith and Hawthorne 1974). This recipe appears to be an observation from a process inherited from the Saracens, who were a nomadic tribe from the Arabian Peninsula notably mentioned by the fourth-century Roman Soldier and Historian Ammianus Marcellinus (Marcellinus and Yonge 1911). Pliny recognised these tribesmen as the wandering Scenitae folk, known to the Greeks simply as the 'Tent People', due to their tents made from the hair of goats (Bostock and Riley 1855; Pliny and Rackham 1938). ${ }^{50}$ The connection between Arabs and Dionysus as a deity is strong regarding their cult, as it was believed that the Arabs were taught or were aware of the mysteries of Dionysiac concepts and his vines from the Nabataean Kingdoms, ${ }^{51}$ with their chief deity being Dusares - which is Dionysus (Retso 2003; Lurker 2004). ${ }^{52}$

A fifteenth-century Iberian recipe ${ }^{53}$ explains processes on how to prepare unbreakable glass using the blood of a he-goat mixed with vinegar (Palomar, Hidalgo and Vilarigues 2018). Yet the theory of unbreakable or flexible glass manufactured by artisans is old and can be dated back to a Roman legend where Pliny recalls the production of flexible glass being destroyed with the artisan put to death by Emperor Tiberius for making such a product which may have jeopardized the initial industry at the time (Pliny and Rackham 1938).

47. Wilson, An Alchemical Manuscript by Arnaldus de Bruxella, 202-405. There was an author from thirteenth/fourteenthcentury who took the name of Geber known as the Latin Pseudo Geber and attributed Jabir ibn Hayyan's work in a manuscript called Summa Perfectionis Magisterii.

48. MSS - Corning Museum of Glass, (Corning NY), Rakow Research Library Ms. 5.

49. For further study see: Ameer, A Short History of the Saracens.

50. Pliny, Nat. Hist, 5.12 .

51. Nabataean Kingdom - seventh-century BC until second-century AD.

52. Lurker, The Routledge Dictionary of Gods and Goddesses, Devils and Demons, 54. Retso, The Arabs in Antiquity, 605. Durares (Duš-šara) - he was equated with the Greek god Dionysus and represented the vine, in the area between the Red Sea and Dead Sea in the Nabataea and southern Syria. The Saracens in the ancient city of Elusa were said to have worshipped Lucifer - the Light Carrier, also known as the planet Venus as the 'Morning Star' being 'Durares' - Kawkabta. 
Manuscript recipe $\$ 58$ I $\$ 333-c .1431$

Le Begue MS De Diversis Coloribus, Experimenta De Coloribus, Paris, Bibliothèque nationale de France, Latin 6741 - (Merrifield 1967).

\begin{tabular}{l|l}
\hline \multicolumn{1}{c|}{ English Translation } & \multicolumn{1}{c}{ Original Latin Text } \\
\hline $\begin{array}{l}\text { [\$58] To temper iron so that it will be hard } \\
\text { enough to cut precious stones -heat the iron in } \\
\text { the fire to a convenient heat, and extinguish } \\
\text { [by quenching it] in the blood of a goat in the } \\
\text { month of March. }\end{array}$ & $\begin{array}{l}\text { [\$58] Ad temperandum ferrum, quod erit tam } \\
\text { durum, quod de ipso poterunt incidi duri } \\
\text { lapides preciosi - Callefac ferrum ad ignem ut } \\
\text { convenit, et extingue in sanguine irce libidine } \\
\text { amoris inflammati, id est in marcio mense. }\end{array}$ \\
\hline $\begin{array}{l}\text { English Translation } \\
\begin{array}{l}\text { [\$333] The following is for tempering iron } \\
\text { and steel - When the he-goat is in heat take } \\
\text { his blood and temper your iron or steel in this; } \\
\text { it then becomes very hard. The he-goat is an } \\
\text { animal whose Latin name is 'hyrcus'. }\end{array}\end{array}$ & $\begin{array}{l}\text { Original French Text } \\
\text { ainsi-Quant le bouc est en amour, se on prent } \\
\text { son sang, et on y trempe dedens fer ou acier. } \\
\text { Il est moult dur, et le bouc est beste que on } \\
\text { nomme en Latin yrchus. }\end{array}$ \\
\hline
\end{tabular}

The hardening technique for metal is described in Le Begue's fifteenth-century manuscript: De Diversis Coloribus - recipe $§ 58$, on how to temper iron for cutting precious stones and was copied from an earlier book written by Johannes Alcherius, from Milan and Paris in the late fourteenth-century, c.1398 (Merrifield 1967). It is possible that some of the goat's blood recipes to soften glass may have been misinterpreted and perhaps misunderstood regarding the actual practical application which involved blood. Yet the softening process cannot be ruled out if the glass - or rock crystal, or even counterfeited gems such a amber are artificially made to look real using natural materials. ${ }^{55}$ These would eventually become soft if heated on a slow (low heated) fire or if placed into fresh goats blood, as their normal blood temperature is about $102^{\circ} \mathrm{F} / 39^{\circ} \mathrm{C}$, or much higher if the animal is under extra stress (Alam, et al. 2011).

54. Burkert, Greek Religion, 164, 237-38; Roberts, Dictionary of the Classical World, 41. Late February-March - the time when the sap in plants rises and the start of many Spring festivals celebrated in different religions. The Greek Anthesteria festival celebrated in the Spring relates to Dionysus and opening of new wine. Buckthorn leaves were said to be chewed at the festival to keep away destructive spirits.

55. Clarke, Medieval Trades, 54. (Cambridge, Trinity College MS 0.9.39). Counterfeiting of Amber-Recipe $\$ 21$ explains the process to make artificial amber using egg white, gum arabic, linseed oil, saffron mixed together and placed inside of the gut of sheep then left to dry in the sun. 
Manuscript recipe $\$ 4.38 .6 B-c .1400$

The Liber diversarum arcium, Montpellier, MS H 277, fonds ancien, Bibliothèque interuniversitaire, section médecine, France - (Clarke 2011).

\begin{tabular}{l|l}
\hline \multicolumn{1}{c|}{ English Translation } & \multicolumn{1}{c}{ Original Latin Text } \\
\hline $\begin{array}{l}\text { [\$4.38.6B] Blood of a goat, and of a goose, } \\
\text { and the amurca of oil }{ }^{57} \text { and vinegar, in equal } \\
\text { quantities on a slow fire, heated in a vessel: it } \\
\text { softens glass and gems that they can be cut } \\
\text { with iron. }\end{array}$ & $\begin{array}{l}\text { [8 } \\
\text { [\$4.38.6B] Sanguis yrci et anseris / et amurca } \\
\text { olei etum equaliter lento igne / in vase } \\
\text { calefacto / vitrum et gemas mollit ita ut scindi } \\
\text { possint ferro. }\end{array}$ \\
\hline
\end{tabular}

\section{Ivy Berry Juice}

Additionally, ivy berry juice has a range of alternative uses other than tempering metals in forges. Dioscorides' explains ivy was an additive ingredient when making medicinal wine to treat headaches by cooking leaves and berry clusters (Beck 2011). He wrote in his notable book on medicinal wine ${ }^{59}$ recipes made using herbaceous and hallucinogenic plants and details ivy juice with leaves used to treat numerous health conditions - possibly known centuries earlier in Dionysiac worship outside of Greece (Clarke 2014; Beck 2011). Aretaeus the Cappadocian, a second-century Greek physician also mentions in his medicinal text the usage of ivy juice as one of many plant juices to deal with hysteria and fits of delirium and can be an added ingredient in a remedy for treating madness and brain disorders from that period (Aretaeus and Adams 1856; Ali 2018). According to Socrates (c.469-399 BC), the Thracian culture relating to Dionysus used a 'leaf remedy technique' inscribed with incantations to treat headaches and may have originally used real leaves to write on before making durable substitutes out of metal to form magical charms (Faraone 2010). Images found on Greek vases show ivy headbands worn whilst drinking wine with bunches of ivy berries attached to thyrsus staffs grasped by the hands of dancing maenads - whether in ritual practices or acting out wild primitive performances expressed and

56. Budge, The Gods of the Egyptians Vol. 2, 94-99; A Dictionary of Scientists, 207-8. The goose is attributed to the Greek God Hermes - the Egyptian God Geb or Seb (Earth) in relation with the element of Air. The Aristotelian fourelement concept, Earth, Water, Fire, Air, which was adopted by the ninth-century Arabian Alchemist Jabir ibn Hayyan,

57. Clarke, Mediaeval Painters Materials and Techniques, 228. Amurca is a watery liquid expressed from olives before pressure is applied to extract the oil, it is also used to improve heating qualities of firewood.

58. Ibid., 158. Recipe $§ 4.38 .6 \mathrm{~B}$ appears to be in note-form: the ingredients, measurements and purpose, ending with "to cut with iron [knife or tool]".

59. De Materia Medica. 
inspired by earlier civilisations (Kalke 1985) ${ }^{60}$ Herbal wine practices were widely known in ancient Egypt for thousands of years before the Greek Empire and was mentioned within the pyramid texts in early dynasties, 'as the cometh of the Lord of the Wine', where fermented herbs and narcotic plants were made into healing wine (Barnard, et al. 2011; McGovern 2009).

If the exotic orgies and intimate rituals influenced by Dionysiac rites led to unwanted pregnancies, ivy stalks smeared with honey are said to be deposited into the uterus to draw menstrual periods consequently resulting in the termination of the fetuses (Beck 2011). It was known that prescriptions to deal with such cases were indeed practiced in ancient Greece, with abortions performed away from the eyes of men in secrecy possibly part of ritual activity (Kapparis 2002). The toxicity of ivy berries if taken internally in large concentrated doses can cause sterility as one of its side effects and is said to have been used as a method for birth control preventatives in the form of ancient Greek wine (Bunney, et al. 1992; Bullough 2001). Other than wine, it can be said that using ivy berries to make paint in earlier classical periods is plausible, though little evidence exists to suggest this ever happened. However, past cultures have used ivy berries as a temporary hair dye and were known for their medicinal properties. It was prescribed by a Greek botanist and philosopher Theophrastus ${ }^{61}$ centuries before Dioscorides and Aretaeus, and acknowledged the dyeing properties of particular plants in his book 'Historia Plantarum' also called 'The Enquiry into Plants’ (Beck 2011; Flemestad 2014).

\section{Conclusion}

The ivy plant has clung onto the imagination of creative expression since classical poets wrote plays about ancient cult rituals and how they transformed the mindset of everyday communities. They encountered emotional practices derived from ancient culture's complexities, whether by re-enacting rituals through dance and music, or creating inner spirits by forming non-objective realities in bringing out ideas and beliefs into the wider societies' psyche (Harrison 1913). Within the modern world, the hidden magic has soberly dissolved within the perspectives of scientific thinking and over time have become separated from the hypnotic trance of ceremonial dances and earlier magical practices and beliefs as a way of life. The tablet recipes explored in this study are practical elements that may have once been part of sacred ritual practices rooted in the craftsman's work - to be known as 'ritual recipes'. This craft may date back to pre-dynastic periods from alternative cultural beliefs, with surviving pieces of knowledge giving only a glimpse through the keyhole of creative expression and visual representation. Ivy has been documented in numerous

60. Kalke, The Making of a Thyrsus, 409-426; Cooper, Traditional Symbols, 172. Thyrsus - a fennel rod staff adorned with ivy berries and grape vine, tipped with a pine cone and is symbolic to Dionysian worship. An ivy spear and phallic symbol.

61. Taylor, The Oxford companion to the garden, 468. Theophrastus (c.371-287 BC) - wrote two important botanical works: Historia Plantarum and De Causis Plantarum, and studied under Plato and an associate and successor of Aristotle. 
medieval recipes with the association of goat's blood, holding possible connections to the wild cults of Dionysian worship of earlier faiths relating to the goat or ram-headed god Ba. ${ }^{62}$

Through the symbolism and belief systems, the golden tablets have been designed for the safe passage within the underworld, possibly originating from earlier cultures comparable to that of Osiris or pre-existing cults from a broader region of the Middle-East (Tadmore 2003; Metropolitan Museum of Art 1986). ${ }^{63}$

The evidence of sacred tablets has been discovered in many ancient graves and inscribed with confirmation of Orpheus and Bacchus rites to the goddess and spirit of the Heavens. They maintain the kinship to ivy and the goat, both attributed to the god figure Dionysus and his worshippers, with variations of his name integrated into different cultures across time. Recipes from the LDA manuscript describes processes for changing copper tablets into a golden colour by heating the metal then applying goat's blood and ivy juice, methods supported by the alchemic laws of science (Hinshelwood 1922). The recipes give steps on how to make a golden colour using blood and berry juice from the rapid cooling and tempering processes used for strengthening metals in antiquity.

However, there is no direct evidence to suggest the LDA recipes $\$ 4.37 .1 \mathrm{C}$ and $\S 4.38 .6 \mathrm{~B}$, or other recipes, were signifying to supply tablets for religious purposes, but may have remained part of the wider society who were admittedly religious. Furthermore, within the LDA's introduction and final pages, it begins and ends with religious formalities in reflecting the medieval period and in some recipes Greek or Roman. Other LDA recipes indicate processes for decorating divine relics and religious diadems, perhaps generated within the workshop trade by providing artists services and skills to religious centres.

It is difficult to say if some of the LDA recipes originated from ancient Greece and elsewhere, or whether they were copied from earlier books that escaped the thousands of burnings of Greek and Egyptian text in the first-fourth-centuries of the Christian era (Betz 1986). But we can be sure that the Greek, Roman and earlier periods of history did use the blood of the goat and other animals for numerous rituals relating to primitive belief systems

62. Lurker, The Routledge Dictionary of Gods and Goddesses, Devils and Demons, 27. Ba - ram / he-goat, a philoprogenitive god object of veneration from women who wanted off-spring - a manifestation of the Egyptian God Re in the form of the billy goat in the Late Egyptian Period.

Gettings, Dictionary of Demons: A Guide to Demons and Demonologists in Occult Lore, 46; Mac Góráin, Dionysus and Rome, 231-234. This may have changed into Baphomet or the Devilish Sabbatic Goat, a demonic beast portrayed by religions against pagan worship or idols relating to earlier practices of different beliefs and demonising other faiths through propaganda and religious prejudice. This started to rematerialise in the fourth-century AD with Firmicus Maternus of Syracuse in Sicily who launched an attack on Dionysus and Paganism laying the foundations for eradicating non-Christian beliefs in the fourth-coming centuries. The Sabbatic Goat may have later become a corruption of Mohammed, as the head of Baphomet was sometimes called Maumet or Mahomst.

Hall and Clark, Dictionary of Subjects and Symbols in Art, 207,259. The ram is also an attribute of Roman God Mercurius (Greek Hermes), the protector of flocks whilst holding the Caduceus wand/staff being the messenger of Jupiter (Greek Zeus, father of Dionysus).

63. Tadmore, The Nahal Mishmar Hoard, 274-277. Metropolitan Museum of Art, Treasures of the Holy Land. Ceremonial goat and ram copper sceptres, obsidian glass mirrors (natural black volcanic glass mined perhaps from Melos in the Greek Islands or Armenia) and many other artefacts including copper crowns were found from the Cave of the Treasure, Nahal Mishmar, Judean Desert, near the Dead Sea; IAA:1961-88-Israel Antiquities Authority. They were made using a lost wax casting technique - Chalcolithic Period c.4500-3500 BC and believed to belong to the Temple of Ein Gedi (Spring of the Kid) made by the tribes of trader-smiths living in the Judean Desert caves. 
whilst honouring their gods at festivals or in private ceremonies. Some of the text which survived inside medieval manuscripts may be fractional echoes or ritual recipes which are reinterpreted technical processes and probably proceeded from past cultural practices detached from their original concepts. Yet the recipes before $\S 4.38 .6 \mathrm{~B}$ within the same chapter, references factors that are considered Greek or perhaps of Greek influences revisited. For example, 'Greek fire' made with wine and 'a satyr statue' to be made in an anthromorphic hearth blower that can be dated back to the Roman period or earlier (Clarke 2011; Martin 2016; Rowland and Howe 2001). ${ }^{64}$

The specific purpose of the tablets described in the LDA manuscript provides limited insight to their primary use, yet we can affirm that copper can be designed as pieces of jewellery, everyday decoration, or simply golden coloured plaques symbolically fashioned for the front of sacred books highlighting their cultural importance and spiritual value (Hawthorne and Smith 1979). These pieces of art may have been produced by the skill of the craftsman's hand inside the fires of the Alchemist's forge where basilisks grow, serving the purpose to communicate public laws for civil obedience or oath-taking, anointed with the fresh blood of a goat enforced by the authorities of ancient Greece and elsewhere. From within antiquity, ivy shaped amulets were created for devoted members of the ancient cult of Dionysus, with secretive verses of sacred rituals embedded and inscribed with the magical incantations of guarantees in the afterlife. They were believed to favour the dead when they proceeded through the timeless dimensions of Hades, to discover their final verdict and unknown fate whilst wandering within the shadowy depths of the underworld.

64. Clarke, Mediaeval Painters' Materials and Techniques, 157, 226-7; Martin, The Aeolipile, 2016. Recipe §4.37A.2. Roman example of an anthromorphic or aeolipile are described by the first-century architect Vitruvius in his 'Ten Books on Architecture' and was known earlier by the Aristotle (c.384-322 BC). 


\section{Bibliography}

A Dictionary of Scientists. Oxford University Press, 1999.

Alam, M M, et al. "Effect of heat stress on behavior, physiological and blood parameters of goat." Progressive Agriculture 22, no. 1-2 (2011): 37-45.

Ali, Nabil. "Colourants Made from Aphids and Ivy Gum." Heritage Science 6, no. 38 (2018).

Allen, James Peter, and Peter Der Manuelian. The Ancient Egyptian Pyramid Texts. 2nd. Atlanta, Georgia: SBL Press, 2015.

Ameer, Ali. A Short History of the Saracens. London: Routledge, 2010.

Aretaeus, and F Adams. The extant works of Aretaeus, the Cappadocian. London: The Syndenham Society, 1856.

Barnard, Hans, Alek N Dooley, Gregory Areshian, Boris Gasparyan, and Kym F Faull. "Chemical evidence for wine production around 4000 BCE in the Late Chalcolithic Near Eastern highlands." Journal of Archaeological Science (Elsevier) 38, no. 5 (2011): 977-984.

Beck, Lily Y. Pedanius Dioscorides of Anazarbus. De Materia Medica. Texts and Studies in Classical Studies. Hildesheim: Olms-Weidmann, 2011.

Betz, Hans Dieter. The Greek magical papyri in translation, including the Demotic spells. Chicago \& London: Chicago University Press, 1986.

Bildhauer, Bettina. "Medieval European Conceptions of Blood: Truth and Human Integrity." Journal of the Royal Anthropological Institute (Wiley Online Library) 19 (2003): S57-S76.

Bostock, J, and HT Riley. The Natural History of Pliny. London: Taylor and Francis, 1855.

Braund, Susan H. Civil War by Lucan. Oxford: Oxford University Press, 1992.

Bucklow, S. "Impossible Recipes." In Sources and Serendipity: Testimonies of Artists' Practice, by Erma Hermens and Joyce Townsend, 18-22. London: Archetype Publications, 2009.

Budge, Wallis. The Gods of the Egyptians. Vol. 1. 2 vols. New York: Dover Publication, 1969.

-. The Gods of the Egyptians. Vol. 2. New York: Dover Publication, $1969 \mathrm{~b}$. 
Bullough, Vern L. Encyclopedia of Birth Control. ABC-CLIO, 2001.

Bunney, Sarah, Jiří Stodola, Jan Volák, and Františk Severa. The illustrated encyclopedia of herbs: Their medicinal and culinary uses. New York: Chancellor Press, 1992.

Burkert, Walter. Greek religion. Cambridge MA: Harvard University Press, 1985.

Bury, Robert Gregg. Plato in Twelve Volumes. Vols. 10-11. Cambridge MA: Harvard University Press, 1967.

Clarke, Mark. "Dioscorides as an art technological source." In Making and Transforming Art: Technology and Interpretation, edited by Hélène Dubois, 1-9. London: Archetype Publilcations, 2014.

-. The Art of all Colours: Mediaeval Recipe Books for Painters and Illuminators. London: Archetype Publications, 2001.

-. Mediaeval Painters Materials and Techniques: The Monpellier Liber diversarum arcium. London: Archetype Publications, 2011.

-. The Crafte of Lymmyng and the Maner of Steynyng. Middle English Recipes for Painters, Stainers, Scribes, and Illuminators. Oxford: Oxford University Press, 2016.

-. Tricks of the Medieval Trades. The Trinity Encyclopedia: A Collection of FourteenthCentury English Craft Recipes. London: Archetype Publications, 2018.

Cotterell, Arthur. A Dictionary of World Mythology. Oxford: Oxford University Press, 2003.

Delahunty, Andrew, and Sheila Dignen. Oxford Dictionary of Reference and Allusion. 3rd. Oxford: Oxford University Press, 2012.

Dodds, Eric Robertson. "Maenadism in the Bacchae." Harvard Theological Review (Cambridge University Press) 33, no. 3 (1940): 155-176.

Eastaugh, Nicholas, Valentine Walsh, Tracey Chaplin, and Ruth Siddall. The Pigment Compendium: A Dictionary of Historical Pigments. Oxford: Elsevier ButterworthHeinemann, 2004.

Edmonds, Radcliffe G. Myths of the Underworld Journey: Plato, Aristophanes, and the 'Orphic' Gold Tablets. Cambridge: Cambridge University Press, 2004.

Ekroth, Gunnel. "Animal Sacrifice in Antiquity." In The Oxford handbook of Animals in Classical Thought and Life, by Gordon L Campbell, 324-354. Oxford: Oxford University Press, 2014. 
Ekroth, Gunnel. "Blood on the altars? On the treatment of blood at Greek sacrifices and the iconographical evidence." Antike Kunst, 2005: 9-29.

Evans, Ulick Richardson. "The Colours due to Thin Films on Metals." Proceedings of the Royal Society of London. Series A, Containing Papers of a Mathematical and Physical Character (The Royal Society London) 107 (1925): 228-239.

Faraone, Christopher A. A Socratic Leaf Charm For Headache (Charmides 155b--157c), Orphic Gold Leaves, And The Ancient Greek Tradition Of Leaf Amulets. Vol. 127, in Myths, martyrs, and modernity: studies in the history of religions in honour of Jan N. Bremmer, by Jitse et al Dijkstra, 145-166. Brill, 2010.

Fischer-Hansen, Tobias, and Birte Poulsen. From Artemis to Diana: The Goddess of Man and Beast. Vol. 12. Copenhagen: Museum Tusculanum Press, 2009.

Flemestad, Peder. "Theophrastos of Eresos on Plants for Dyeing and Tanning." In Purpureae Vestes IV: Textiles and Dyes in antiquity. Production and Trade of Textiles and Dyes in the Roman Empire and Neighbouring Regions, by $\mathrm{C}$ et al Alfaro, 203-9. Valencia: University of Valencia, 2014.

Frazer, James George. The Golden Bough a Study in Magic and Religion. Oxford: Oxford University Press, 1994.

Gaillard, Yvan. et al. "An Unusual Case of Death: Suffocation Caused by Leaves of Common Ivy (Hedera helix). Detection of Hederacoside $\mathrm{C}$, a-Hederin, and Hederagenin by LC-EI/MS-MS." Journal of Analytical Toxicology (Oxford University Press) 27, no. 4 (2003): 257-262.

Gettens, Rutherford J, and George L Stout. Painting Materials: A Short Encyclopaedia. New York: Dover Publications, 1966.

Gettings, Fred. Dictionary of Demons: A Guide to Demons and Demonologists in Occult Lore. London: Guild Publishing, 1988.

Golder, Herbert. Euripides: The Bacchae. New York: Applause Theatre \& Cinema Books, 2001.

Graf, Fritz, and Sarah Iles Johnston. Ritual Texts for the Afterlife: Orpheus and the Bacchic Gold Tablets. 2nd. London: Routledge, 2013.

Hall, James, and Kenneth Clark. Dictionary of Subjects and Symbols in Art. London: John Murray, 1974.

Harrison, Jane Ellen. Ancient Art and Ritual. London: Henry Holt, 1913. 
Hawthorne, John G, and Cyril Stanley Smith. On Divers Arts: The Foremost Medieval Treatise on Painting, Glassmaking, and Metalwork. New York: Dover Publications, 1979.

Hendrie, Robert. An Essay Upon Various Arts, by Theophilus, forming an Encyclopaedia of Christian Art of the Eleventh Century. London: John Murray, 1847.

Henrichs, Albert. "Loss of Self, Suffering, Violence: the Modern View of Dionysus from Nietzsche to Girard." Harvard Studies in Classical Philology 88 (1984): 205-240.

Hinshelwood, Cyril Norman. "Proceedings of the Royal Society of London. Series A, Containing Papers of a Mathematical and Physical Character." The Royal Society of London (The Royal Society of London.) 102 (1922): 318-328.

Hornblower, Simon, Antony Spawforth, and Esther Eidinow. The Oxford Classical Dictionary. 4th. Oxford: Oxford University Press, 2012.

Howatson, M C. The Oxford Companion to Classical Literature. 3rd. Oxford: Oxford University Press, 2011.

Johnson, Roger A. Peacemaking and Religious Violence: From Thomas Aquinas to Thomas Jefferson. Eugene: Wipf and Stock Publishers, 2009.

Jordan, Michael. Encyclopedia of gods: Over 2,500 deities of the world. London: Kyle Cathie Ltd, 2002.

Joyce, Jane Wilson. Pharsalia by Lucan. Ithaca: Cornell University Press, 1993.

Kalke, Christine M. "The Making of a Thyrsus: the transformation of Pentheus in Euripides' Bacchae." The American Journal of Philology 106, no. 4 (1985): 409-426.

Kapparis, Konstantinos A. Abortion in the Ancient World. Bristol Classical Press, an imprint of Bloomsbury Publication, 2002.

Lamb, W R M. Plato: [in Twelve Volumes]. Cambridge MA: Harvard University Press, 1925.

Law, Jonathan, and Richard Rennie. A Dictionary of Chemistry. 8th. Oxford: Oxford University Press, 2020.

Lurker, Manfred. The Routledge Dictionary of Gods and Goddesses, Devils and Demons. London: Routledge, 2004.

Mac Góráin, Fiachra. Dionysus and Rome: Religion and Literature. Vol. 93. Walter de Gruyter GmbH \& Co KG, 2019. 
Marcellinus, Ammianus, and Charles D Yonge. The Roman History of Ammianus Marcellinus. London: Bells \& Sons, 1911.

Martin, Craig. "The aeolipile as experimental model in early modern natural philosophy." Perspectives on Science 24, no. 3 (2016): 264-284.

Massey, Gerald. Ancient Egypt: The Light of the World. reprint. New York: Cosimo Inc, 2007.

McGovern, Patrick E et al. "Ancient Egyptian Herbal Wines." Proceedings of the National Academy of Sciences 106, no. 18 (2009): 7361-7366.

Merrifield, Mary P. Medieval and Renaissance Treatises on the Arts of Painting: Original Texts with English Translations, Two Volumes Bound as One. New York: Dover Publications, 1967.

Metcalfe, Alex. Muslims and Christians in Norman Sicily: Arabic-Speakers and the End of Islam. London: Routledge, 2003.

Metropolitan Museum of Art. Treasures of the Holy Land: Ancient Art from the Israel Museum. Edited by Kathleen Howard. New York: Metropolitan Museum of Art, 1986.

Moran, Bruce. Distilling knowledge: Alchemy, chemistry, and the scientific revolution. Cambridge: Harvard University Press, 2009.

Nicholson, Paul T, and Ian Shaw. Ancient Egyptian Materials and Technology. Cambridge: Cambridge University Press, 2000.

Otto, Walter F. Dionysus: Myth and Cult. Bloomington: Indiana University Press, 1965.

Palomar, Teresa, Rafael Javier Díaz Hidalgo, and Marcia Vilarigues. "Pigments, Vinegar and Blood: Interpretation and reproduction of glassy materials from medieval manuscripts H-490." International Journal of Applied Glass Science (The American Ceramic Society \& Wiley), 2018: 555-565.

Patai, Raphael. The Jewish Alchemists: A History and Source Book. New Jersey: Princeton University Press, 1995.

Patrich, Joseph. Was Dionysos, the Wine God, venerated by the Nabataeans? Vol. 17. ARAM Periodical, 2005.

Peck, Harry Thurston. Harper's Dictionary of Classical Literature and Antiquities. Vol. 1. New York: Harper and Brothers, 1897.

Pliny, and Harris Rackham. Natural History. Vol. 3; 8. London: Heinemann, 1938. 
Plutarchus. Moralia. With an English translation by Frank Cole Babbitt. London: Harvard University Press, 1927.

Rackham, Harris. Aristotle in 23 Volumes. Vol. 20. Cambridge MA: Harvard University Press, 1952.

Renouf, Le Page. The Egyptian Book of the Dead. London: The Society of Biblical Archaeology, 1893.

Retso, Jan. The Arabs in Antiquity: Their History from the Assyraians to the Umayyads. New York: Routledge, 2003.

Roberts, John. The Oxford Dictionary of the Classical World. Reprint. Oxford: Oxford University Press, 2016.

Rowland, Ingrid D, and Thomas Noble Howe. Vitruvius: Ten Books on Architecture. Cambridge: Cambridge University Press, 2001.

Schøyen. The Earliest Greek Alphabet, The Schøyen Collection MS (108). 2013. https://www.schoyencollection.com/palaeography-collection-introduction/earlywriting-introduction/first-alphabets/earliest-greek-alphabet-ms-108 (accessed April 03, 2017).

Simonsohn, Shlomo. The Jews in Sicily: 383-1300. New York: Brill, 1997.

Smith, Cyril S, and John G Hawthorne. "Mappae Clavicula: A Little Key To The World of Medieval Techniques." Transactions Of The American Philosophical Society 64, no. 4 (1974): 1-128.

Stadelman, William J, and Owen J Cotterill. Egg Science and Technology. 4th. New York: The Haworth Press, 1995.

Tadmore, Miriam. The Nahal Mishmar Hoard from the Judean Desert. Vol. 32, in Near Eastern Archaeology: a Reader, by Suzanne Richard, edited by Suzanne Richard, 274-277. Winona Lake: Eisenbrauns, 2003.

Taylor, P. The Oxford companion to the garden. Oxford: Oxford University Press, 2008.

The Historical Metallurgy Society, England, interview by Ali. The Colchester Medieval Festival \& Oyster Fayre Market $(06$ 03, 2017).

Waite, Arthur E. A Lexicon of Alchemy by Martin Rulandus the Elder. London: John M. Watins, 1964.

Waterfield, Robin, and Carolyn Dewald. Herodotus: The Histories. Oxford: Oxford University Press, 2008. 
Wilson, W J. "An Alchemical Manuscript by Arnaldus de Bruxella." Osiris 2 (1936): 220_ 405.

Winnington-Ingram, Reginald P. Euripides and Dionysus: An Interpretation of the Bacchae. Bristol: Bristol Classical Press, 2003.

Zeskoski, Srebrenka Bogovic. "Historical Pigments and the Role of Alchemy in their Production: an Interdisciplinary Study." Portal-Godisnjak Hrvatskog Restauratorskog Zavoda, 2017: 21-41.

(C) 2020 Nabil Ali. 